\title{
PRZYPIS DO IKONOGRAFII IN MEMORIAM TALA POTOCKA
}

\author{
Nina TAYLOR-TERLECKA (Oksford)
}

\section{Reminiscencja}

Było to więc tak. Latem 1979 roku długo podszeptywano na korytarzach ówczesnej School of Slavonic and East European Studies, że na dwa lata przed emeryturą profesor Jerzy Pietrkiewicz odchodzi z uczelni na własne żądanie - a to z przyczyn do końca niewyjaśnionych. Wywołało to szok, zawód i chwilową rozpacz wśród studentów. Gdy profesor sam powiadomił słuchaczy o swej decyzji, zachęcał nas do walki o odpowiedni standard naukowy naszych wykładowców, żebyśmy nie dopuszczali do obniżenia należytego poziomu. Konkretnych wskazówek co do podejmowania tej walki jednak nie podał.

Na pożegnanie, w dzień św. Piotra i Pawła, zaprosił wszystkie trzy roczniki polonistów — w sumie około dwunastki swoich uczniów — na wieczór do domu, ujawniwszy zawczasu pilnie strzeżony adres. Choć wiadomo było, że codzienną miskę gotowanych kartofli zapija tylko szampanem, przyszliśmy gromadnie i grzecznie na Hampstead z kwiatami i (bodaj) koniakiem. Czym profesor nas poczęstował, nikt już nie pamięta, za to czarował młodych gości, deklamując głosem guślarza jakiś wiersz onomatopeiczny o wspaniałym półpogańskim wybrzmieniu.

Na nasze grono, rozmieszczone po długiej kanapce i kilku fotelach, patrzyła ze srebrnej ramki urzekająco piękna dama; godna najlepszego pędzla malarskiego, mogłaby zasilić fantazję Teofila Gautiera, Hoffmana czy Balzaca. Spojrzenie miała nieco błagalne a zniewalające, a wyraz bezmiernego oddania na twarzy. Uroda aż biła z niej, ogarniała cały obszar przestrzennego salonu, zauroczyła towarzystwo. Wzbudziła nieuniknienie notoryczną wścibskość i studenterii.

Koledzy z roku — zwłaszcza Duży Wicuś — z lekka zaczęli trącać mnie łokciem. „To ty zapytaj profesora, kto to...?” Pytanie i tak było zupełnie zbędne, a imię sfotografowanej nieistotne. Wyraz oczu mówił wszystko - wniebogłosy. Pani była wszechobecna. Żyła poza życiem i poza śmiercią.

W pewnej chwili profesor poprosił mnie do biurka i wyciągnął numer „Wiadomości” z 1974 roku ${ }^{1}$. Był tam jego przekład wiersza Williama Wordswortha oraz portret

\footnotetext{
${ }^{1}$ Wiadomości 1974 nr 44(1493).
} 
pani ze srebrnej ramki, opatrzony dedykacją: „Tali poświęcam”. Potem przy półce z książkami wskazał mi trzytomową edycję listów Zygmunta Krasińskiego do Delfiny Potockiej, z któregoś z tomów zwisała na wstążeczce owalna miniatura słynnej Didyszy-Diali. Zadał tylko pytanie: „Widzisz podobieństwo? Kojarzysz?”. Przytaknęłam. Nic więcej. Zagadka rozwiązana, sekret odtajniony — a przecież tożsamość tajemniczej damy była dostępna każdemu czytelnikowi „Wiadomości”, i nie tylko.

\section{Genealogia i heraldyka}

Było to pięć lat po jej zgonie. Dama z portretu to zmarła 8 września 1974 roku Natalia Maria Janina hrabina Potocka z Podhajec h. Pilawa. Urodzona 21 września 1929 roku w Jabłonnie, była córką Maurycego hr. Potockiego (1894-1949), właściciela tejże Jabłonny; wnuczką Augusta Potockiego (1847-1905), pioniera sportu wyścigowego i birbanta warszawskiego), i Eugenii z Wojnicz-Sianożęckich, córki Eugeniusza Wojnicz-Sianożęckiego h. Nałęcz i Leontyny Hołyńskiej h. Klamry; i prawnuczką Maurycego (1812-1879) i Ludwiki Bóbr-Piotrowickiej (1825-1890). Ojcem jej był weteran trzech wojen: I światowej, polsko-ukraińskiej i polsko-sowieckiej. Żył potem ze stopniowej parcelacji dóbr i dochodów z nieruchomości, był współtwórcą Automobilklubu Polskiego, uczestnikiem rajdów samochodowych i kolekcjonerem samochodów wyścigowych, a także działaczem Polskiego Związku Łowieckiego. Po unieważnieniu w 1928 roku pierwszego małżeństwa z ks. Teresą z Woronieckich h. Korybut — była ona córką Mieczysława Woronieckiego (z rodu Rurykowiczów) i Marii Drohojowskiej — poślubił w 1929 roku Marynę z Gąsiorowskich, primo voto Brydzińską (ur. 1900), tancerkę, aktorkę sceniczną i filmową.

Maryna, córka Stanisława Gąsiorowskiego i Cecylii Rutkowskiej, była uczennicą Szkoły Baletowej Teatrów Warszawskich, od młodego wieku grała w warszawskich teatrach rewiowych, następnie na scenie Teatru Polskiego i Teatru Małego, sukcesy odnosiła w lżejszym repertuarze. Występowała w spektaklach w reżyserii Juliusza Osterwy i Stefana Jaracza. W latach 1923-1926 można było ją oglądać w Teatrze Narodowym, Letnim i Komedia. Do jej znaczących dokonań zaliczyć można rolę Reni w Sezonowej miłości i Tatiany w Urodzie życia, zaś Jan Lechoń zapamiętał na wiele lat dwa jej wcielenia przedwojenne - jako Antosi w Chorym z urojenia i Kory w Nocy listopadowej ${ }^{2}$. Zrezygnowawszy po drugim małżeństwie z kariery scenicznej, urodziła córkę Natalię w 1929 roku. Roman Kramsztyk sportretował ją parokrotnie - w 1932 roku, ,jako aktorkę" a ok. 1935-1936 roku jako Damę z wiewiórka. Komentuje monografistka malarza: „,w rudym zwierzątku być może ukryta jest osobista aluzja lub, co bardziej prawdopodobne, nawiązanie do sławnej Damy z łasiczka Leonarda"3. Pana Hrabiego natomiast wyróżniono w ulotnej literaturze epoki — w numerze primaaprilisowym „Nowych Wiadomości Literackich”. ${ }^{\natural}$ W tym kontekście trzeba by również wspomnieć rzeźbę dłuta Augusta Zamoyskiego.

\footnotetext{
2 J. Lechoń, Dziennik, t. III, oprac. R. Loth, Warszawa 1993, s. 738 (zapis z 29 listopada 1955).

${ }^{3}$ Zob.: R. Piątkowska, Między „Ziemiańska” a Montparnasse'em. Roman Kramsztyk, Warszawa 2004, s. 112. W przypisie na s. 125 autorka przytacza opinię Mieczysława Wallisa: wraz z innymi portretami kobiecymi ,należą do najpiękniejszych rzeczy, jakie Kramsztyk kiedykolwiek namalował lub narysował, stanowią, przynajmniej dla mnie, szczyt jego twórczości dotychczasowej”. M. Wallis, Humanizm Kramsztyka, Wiadomości Literackie 1936 nr 20, s. 8.

${ }^{4}$ Nowe Wiadomości Literackie, Warszawa, nr 1 z 1 kwietnia 1936 r. Zob.: A. Słonimski, J. Tuwim, W oparach absurdu, Warszawa 2008, s. 183.
} 
Za okupacji niemieckiej Brydzińska-Potocka nie grała w teatrach, a hrabia Maurycy współdziałał ze Związkiem Walki Zbrojnej, potem Armią Krajową; w jego kamienicy przy ul. Mazowieckiej 4 mieścił się bar, używany jako lokal kontaktowy Komendy Głównej AK. Po upadku powstania warszawskiego hrabina znalazła się w Krakowie, a hrabia w Ojcowie, gdzie w marcu 1945 roku został aresztowany przez UB. Wyzwolony w sierpniu 1945 roku, przedostał się przez zieloną granicę i na jesieni dotarł do Londynu; jego małżonka z córką przybyła do Anglii dopiero w 1947 roku. W tymże roku 18-letnia Natalia wyszła za mąż za Richarda Jennera (ur. ok. 1920 roku).

Wedle oficjalnych danych związek małżeński Natalii z Jennerem przetrwał 10 lat i zakończył się rozwodem. Tuż po nim pobrała się w 1957 roku z Wincentym Koziełł-Poklewskim, synem Alfonsa i Zofii de Stoeckl. Tym razem małżeństwo przetrwało cztery lata, skończyło się rozwodem w 1962 roku.

\section{Kiedy jeszcze pisywano listy}

Tak więc z grubsza zarysowuje się kronika życiowa pięknej Potockiej — w oparciu o liczne genealogie, m.in. Minasowicza. Nieco inaczej przedstawia się ona w świetle korespondencji. O przyjeździe Maryni i Tali na Wyspę powiadamia Mieczysław Grydzewski na samym początku 1947 roku, donosząc Lechoniowi, że mimo samotności ,„...] ciągle kogoś się spotyka. Niedawno Marynę Potocka z piękną córką na Piccadilly (córkę swatają z młodym Jeleńskim)" "5.

Przez następnych parę lat Lechoń prosi w listach, żeby redaktor pozdrowił, uściskał czy ucałował Marynę Potocką, należącą przecież do jego przedwojennej Warszawy, prosił też o przesłanie jej zdjęcia. Koleje życiowe jej córki zarysowały się burzliwie. Otóż w maju 1948 roku, jak donosi „Grydz”, „,córka Brydzińskiej rozeszła się już ze swoim lordem”. Półtora roku później „Grydz” wciąż uważa Talę za wielką piękność, choć określa ją jako „zupełne zwierzątko”. Do złaknionego plotek Lechonia kreśli bowiem dopisek, poprzedzony i zakończony określeniem, ,znis zcz te kartkę”, że „U Bormanna był Łempicki i Tala Potocka (bardzo ładna, ale zupełne zwierzątko). Podobno jakaś lokatorka podsłuchała, że Tala krzyczała: »leżycie z gołymi dupami na łóżku, a co ja, biedna kobieta, mam z tego «”7. Lechoń odpisał z podziękowaniem „,za list i za smakowite plotki”, komentując przy tym: „Ta o Tali Potockiej wyjątkowo piękna" ". Piękna czy nie piękna, po upływie kilku tygodni redaktor znowu podaje wiadomość: „Tala Potocka pojechała do Ameryki. Podobno ze starszym panem, który ma jedną nogę mahoniową. Nazywa się Baron, ale nie jest baronem"9.

Życie towarzyskie środowiska „Wiadomości” w Londynie stanowiło poniekąd dalszy ciąg przedwojennych stosunków, jakie Tala odziedziczyła po rodzicach: replikowało bliskie sąsiedztwo uliczne - miejska rezydencja Potockich stała przy ulicy Mazowieckiej, parę kroków od Małej Ziemiańskiej. W podobny sposób utrzymywano

${ }^{5}$ List M. Grydzewskiego do J. Lechonia z 18 stycznia 1947, w: M. Grydzewski, J. Lechoń, Listy 1923-1956, z autografu do druku przygotowała, wstępem i przypisami opatrzyła B. Dorosz, t. 1, Warszawa 2006, s. 156.

${ }^{6}$ List M. Grydzewskiego do J. Lechonia z 6 maja 1948, w: M. Grydzewski, J. Lechoń, Listy, s. 184.

${ }^{7}$ List M. Grydzewskiego do J. Lechonia z 9 grudnia 1949, w: M. Grydzewski, J. Lechoń, Listy, s. 268.

${ }^{8}$ List J. Lechonia do M. Grydzewskiego z 2 stycznia 1950, w: M. Grydzewski, J. Lechoń, Listy, s. 273.

${ }^{9}$ List M. Grydzewskiego do J. Lechonia z 10 lutego 1950, w: M. Grydzewski, J. Lechoń, Listy, s. 299. 
też relacje z innymi przedwrześniowymi pięknościami i artystkami. Na pierwszy rzut oka może nieco zdziwić obecność w tym gronie Jerzego Pietrkiewicza, jeżeli pamiętamy jego przedwojenne napaści na pismo i antysemickie nagonki, za które wyrzucono go ze Związku Literatów, a także kpiny i parodie pod adresem poety autentysty na łamach „Wiadomości Literackich”. Pisząc o swoim serdecznym koleżeństwie z redaktorem, sam Pietrkiewicz ujmuje tę sprawę w kilku słowach: „tak to się pozmieniały animozje sprzed piętnastu lat"10. Ale drukował swe utwory w „Wiadomościach” w minimalnym zakresie ${ }^{11}$ i za jego kadencji na uczelni skamandryci byli wciąż na indeksie — uważał bowiem, że należy wykładać i badać tylko pisarzy nieżyjących ${ }^{12}$.

O tych nowych powojennych więziach i układach świadczy reminiscencja profesora z okazji gościnnego występu Marii Modzelewskiej w roli Telimeny, gdy na obchody stulecia śmierci Mickiewicza Leopold Kielanowski wyreżyserował Pana Tadeusza w londyńskim teatrze „Scala”. Zaproszony na spektakl Grydzewski zaklinał Pietrkiewicza, żeby poszedł w jego miejsce. „To była jedna z prób przyjaźni”, pisał po upływie wielu lat. „Zmieniłem poprzednie plany na wieczór. Pójdę, ale co mam robić podczas przerwy, będzie to pewno długa. Znowu jego uśmiech. Rób co chcesz, ale za kulisy nie chodź. Bo powiem Tali. Ona nie lubi aktorek" "13. W pośmiertnym wspomnieniu o Antonim Bormanie pisze o troskliwej przyjaźni łączącej zmarłego z Talą Potocką ${ }^{14}$. Ona zaś pojawia się w garstce listów Bormana do Kazimierza Wierzyńskiego z lat 60. Po wizycie poety w Londynie Borman odwiózł go na lotnisko, po czym zaraz pisał do „Kaziutka najmilszego" wymownie: „Talusia cierpi z powodu niegodziwego amanta, który oświadczył, że jedzie do Szwajcarii — in fact do szpitala, ale nie chciał dać adresu ma pisać tylko na adres jego koledżu w Londynie"15.

Zdawałoby się, że redaktor Grydzewski odgrywał w życiu Potockiej rolę ojcowsko-wujowską, pewnie też obdarzył ją uczuciem więcej niż rodzicielskim. W 1964 roku zaprosił na obiad do „Ogniska” przybyłą wtedy z wizytą do Londynu Elżbietę Wittlin-Lipton, córkę poety. Po jakimś czasie Wittlin pytał „Grydza”: „Ale kto to jest pani Tala, o której wspominasz, że była z Wami na lunchu? Elżunia pisała, że byłeś w towarzystwie pięknej pani Potockiej. Czy to ta sama osoba?" ". Poczta pantoflowa robiła swoje, choć plotki i pogłoski lepiej włożyć między bajki, bo i tak są niesprawdzalne. Tamtego lata Pietrkiewicz przygotował do druku rękopis swego stryja Szymona, z którego - opowiada — ,część tylko ocalała zakopana w ziemi podczas okupacji — był to dokument osobliwy, zapis widzeń mistycznych stryja. Grydzewski wydrukował całość zachowanego tekstu, dał fotografię części rękopisu ${ }^{17}$. Byłem wzruszony, że utwór gospodarza ze wsi Grodzeń został utrwalony w druku""18. Dalej rozpamiętywał:

${ }^{10}$ J. Pietrkiewicz, Pamięć od strony serca, w: „,Wiadomości” $i$ okolice. Szkice $i$ wspomnienia, red. i oprac. M. A. Supruniuk, Toruń 1995, s. 144.

${ }^{11}$ M. Supruniuk, Jerzy Pietrkiewicz w polskim Londynie, czyli o konieczności posiadania adresu, w : Jerzy Pietrkiewicz. Inna wersja emigracji. Materiały Ogólnopolskiej Konferencji Naukowej 11-12 maja 2000 roku w Toruniu, red. B. Czarnecka, J. Kryszak, Toruń 2000, s. 219-240.

${ }^{12}$ Wtedy poza Iwaszkiewiczem żaden ze skamandrytów nie żył.

${ }^{13}$ J. Pietrkiewicz, Pamięć od strony serca, s. 145.

${ }^{14}$ Tamże, Kola, Wiadomości 1968 nr 50 (1185).

15 Biblioteka Polska w Londynie, Archiwum K. Wierzyńskiego (dalej: BPL AKW), list A. Bormana do K. Wierzyńskiego z 23 października 1963.

${ }^{16}$ List J. Wittlina do M. Grydzewskiego z 6 października 1964 r., [w]: J. Wittlin, Listy do redaktorów „,Wiadomości”, oprac. J. Olejniczak, Toruń 2014, s. 299.

${ }^{17}$ S. Pietrkiewicz, Widzenia, wstęp J. Pietrkiewicz, Wiadomości 1964 nr 41(967), s. 3.

${ }^{18}$ J. Pietrkiewicz, Pamięć od strony serca, s. 144. 
Ale drugą osobliwością była osoba korektorki tej właśnie strony „Wiadomości”. Przepiękna Tala Potocka uparła się, żeby ten dość niełatwy tekst pełen zwrotów z dialektu dobrzyńskiego, przeczytać kilka razy i poprawić błędy drukarskie. Siedziała kilka godzin w redakcji. Grydzewski był zachwycony jak nigdy - scena do zapamiętania: Natalia z Jablonny wodząca wzrokiem, linijka po linijce, po tekście mistycznym Szymona ze wsi Grodzeń pod Kikołem.

Ani przedtem ani potem Tala nie robiła żadnej korekty — ta jedyna okazała się wzorowa, bez najmniejszego błędu. Może w tym była magia przenikliwie czarnych oczu. Umarła młodo, w 1974 roku ${ }^{19}$.

Dwa lata po obiedzie z obu młodymi kobietami w „Ognisku” Grydzewski miał pierwszy atak choroby, na którą w końcu zmarł. Jego pierwsze zasłabnięcie Borman przypisywał

[...] przejedzeniu, a może jakiemuś zatruciu wszystkimi tymi świństwami, którymi się napycha w parszywych restauracjach. Nikt niczego mu nie wyperswaduje, a już z całą pewnością nie ja. Tala coś usiłuje mu bałakać, ale i to nie odnosi żadnego skutku, zresztą znów wróciła do narkotyków i od kilku dni bełkocze przez telefon. Przestała chodzić do szpitala i Grydz szaleje w niepokoju, ale nikt mu nie powiedział, co się stało. Udajemy, że ma grypę $e^{20}$.

Po niecałym tygodniu Borman narzeka na tryb życia „Grydza”, że „w jednym tylko tygodniu był $\mathrm{z}$ »narzeczoną« 3 razy w teatrze, tyleż razy w Hostelrii, a ile był u Beryl nikt nie sprawdzał"21. I znowu po upływie siedmiu dopiero dni melduje:

Dziś Mietas wychodzi ze szpitala i na tydzień jedzie do Kossowskich. Po tygodniu wróci do swego „normalnego” życia: Tala, Beryl, sypianie w redakcji na krześle, wstawanie rano z kurami i wracanie na swoje legowisko u Sakowskich późno w nocy. Do tego niezliczona ilość czarnej kawy i tyleż napojów wyskokowych ${ }^{22}$.

Niedługo był z powrotem w lecznicy, w grudniu zaś wedle sprawozdania Bormana „wszyscy chodzą do szpitala: Kossowscy, Tala, Pietrkiewicz, Sakowscy”23.

\section{Zamiast podsumowania}

Te kilka cytatów z Bormanowych listów daje wgląd w parę spraw, przede wszystkim w warsztat i tryb życia redaktora. Rzucają też światło na jego związki osobiste, o których snuto różne hipotezy, zadają kłam pewnym stwierdzeniom ${ }^{24}$, wytyczają parametry jego najbliższego kręgu, określają grono wiernych, nieodstępnych: „wszyscy chodzą do szpitala: Kossowscy, Tala, Pietrkiewicz, Sakowscy" - czyli zaprzysiężona siódemka z Bormanem na czele, zwarta banda razem przemierzająca londyńskie przestrzenie, żeby odwiedzić chorego redaktora. Tala na pewno nie była bez wpływu na tę wspólnotę: pewnie da się tu bez przesady wspomnieć po Norwidowsku o roli kobiety w społeczności jako łączniczki czy pośredniczki między pojedynczym a ogólnym.

Nawet bez druku przekładu z Wordswortha sprawa pięknej Tali była tajemnicą poliszynela. „Zdradzając” wówczas tożsamość nieznajomej ze srebrnej ramki, profesor

\footnotetext{
19 Tamże, s. 144-145.

${ }^{20}$ BPL AKW, list A. Bormana do K. Wierzyńskiego z 5 października 1966.

${ }^{21}$ BPL AKW, list A. Bormana do K. Wierzyńskiego z 11 października 1966.

${ }^{22}$ BPL AKW, list A. Bormana do K. Wierzyńskiego z 18 października 1966.

${ }^{23}$ BPL AKW, list A. Bormana do K. Wierzyńskiego z 16 grudnia 1966.

${ }^{24}$ Zob. np.: T. Terlecki, Grydzewski, Kultura 1970 nr 4 (271); przedr. Spotkania ze swoimi, Wrocław 1999.
} 
wyraźnie wskazywał na koneksje, czy też paralele, z jej imienniczką, sławioną przez „trzeciego wieszcza”. Tyle że - mutatis mutandis — w tej powojennej inscenizacji akcja rozgrywa się na bruku londyńskim, a już tylko symbolicznie na osi magnackiego pałacu i chaty wieśniaczej ziemi dobrzyńskiej. Może to jednak oznaczać, że ten ważki rozdział życia trzeba odczytać w kategoriach powtórki z historii literatury, jako nawiązanie do modelowego romansu ordynata opionogórskiego. Może to być kolejna mistyfikacja albo też wezwanie do snucia niekończących się gdybań, zachęta do hermeneutyki stosowanej - na podstawie niezbadanych, może nieistotnych dokumentów. Pole skojarzeniowe staje się bezbrzeżne.

Laura czy Beatrycze, Delfina czy Maryla, Tala Potocka przyszła na świat z urodą, majątkiem i koligacjami. Miała - pisze Pietrkiewicz — długą podróż w śmierć. W Dzienniku Lechoń zapisał ulubione powiedzonko jej matki, iż „człowiek sam się rodzi i sam umiera". W 1949 roku Maurycy hr. Potocki, rotmistrz I Pułku Ułanów Krechowieckich, kawaler Krzyża Virtuti Militari, Krzyża Walecznych i innych, po nabożeństwie żałobnym został pochowany w kościele cmentarnym St. Mary's Cemetery przy Harrow Road, W.10. Natalia Potocka po wielkich cierpieniach zmarła w Londynie 8 września 1974 roku. Nabożeństwo żałobne odbyło się w kościele Brompton Oratory w czwartek 19 września o godzinie 10:30, po czym nastąpiło spopielenie zwłok w Mortlake o godzinie 11:40. Hrabina przeżyła córkę o 16 lat, zmarła bowiem w 1990 r. w Lailly-en V, Loiret, w wieku 92 lat. Wróciła w trumnie do Londynu, leży tam na cmentarzu Brompton. 